\title{
Trends in seasonal temperatures over the Indian region
}

\author{
Nilesh K Wagholikar ${ }^{1}$, K C Sinha Ray ${ }^{2}$, P N Sen ${ }^{2}$ and P Pradeep Kumar ${ }^{2, *}$ \\ ${ }^{1}$ Sir Parashurambhau College, Pune, Maharashtra 411 030, India. \\ ${ }^{2}$ Department of Atmospheric and Space Sciences, University of Pune, Pune 411 007, India. \\ ${ }^{*}$ Corresponding author.e-mail: ppk@unipune.ac.in
}

An investigation has been carried out to identify the trends in maximum, minimum and mean temperatures and temperature range over the Indian land mass during the winter (January, and February), premonsoon (March-May), southwest monsoon (June-September) and post-monsoon (October-December) seasons by using high resolution daily gridded data set prepared by India Meteorological Department for the period of 1969-2005. It has been observed that the maximum temperatures over the west coast of India show rising trend in winter, southwest monsoon and post-monsoon seasons but the maximum temperatures do not show any significant trend over the other parts of the country. Minimum temperatures show increasing trend over the North Indian states in all seasons and they show an increasing trend over the west coast of India in winter and southwest monsoon seasons. Mean temperature shows an increasing trend over the west coast of India during winter and southwest monsoon seasons. Decreasing trend is observed in the temperature range over North India in all seasons due to increasing trend in minimum temperature.

\section{Introduction}

The Earth's climate has been changing and this change brings about changes in the temperature and rainfall distribution worldwide. However, these changes are not uniform all over the world but vary from place to place. These changes have localized intensity and must be quantified locally to manage the natural resources. As far as the Himalayan region is concerned, variability and trends in temperature are some of the important aspects of climate change studies because impact of climate change on Himalayan ranges affect glaciers and snow cover and river discharge over northwestern Himalayas which is very important as far as water resource management in northern Indian states is concerned. It is also a well known fact that long term changes in temperature have an impact on hydrologic cycle. Disturbance in the hydrological cycle may result in changes in rainfall pattern, extreme precipitation events, and drought conditions, which in turn affect the agricultural, hydrological, and economic planning of the country.

Early investigations by Pramanik and Jagannathan (1954) indicated that the maximum, minimum or mean temperatures all over India did not show any general tendency for an increase or decrease. Hingane et al. (1985) studied the long term linear trend in temperature over the Indian region using station data. Their study shows warming in the mean annual temperatures over the northeast regions of the country. Srivastava et al. (1992) found that the maximum temperatures were showing much larger increasing trends than the minimum temperatures, over a major part of the country. A decreasing trend was observed in temperature over most of the northern parts of the country (north of $23^{\circ} \mathrm{N}$ ), whereas an increasing

Keywords. Temperature; temperature range; trend analysis; India; seasonal trend. 
trend was observed over the southern parts (south of $23^{\circ} \mathrm{N}$ ). The country as a whole showed slightly increasing trend of the order of $0.35^{\circ} \mathrm{C}$ during the last 100 years. Later studies by Rupa Kumar et al. (1994) on the trends for maximum and minimum temperature by using station data for 121 stations for the period of 1901-1987, reported a countrywide increase in mean maximum temperature by $0.6^{\circ} \mathrm{C}$, and decrease in the mean minimum temperature by $0.1^{\circ} \mathrm{C}$. They have also concluded that most of the increases in mean surface air temperature over India are due to the increase in daytime temperature. Some more study on analysis of seasonal and annual surface air temperatures carried out by Pant and Rupa Kumar (1997) has shown a significant warming trend of $0.57^{\circ} \mathrm{C}$ per 100 years over India. They have also reported that post-monsoon and winter seasons are mainly responsible for warming and there is no significant increasing trend for monsoon temperatures over most of parts of the country and a significant decreasing trend is observed over northwest India. Sinha Ray and De (2003) summarized information on trends in the occurrence of extreme events over India by using last 100 years of temperature records and reported an increasing trend of $0.35^{\circ} \mathrm{C}$. They have also reported increasing trend in extreme maximum and minimum temperatures in the south and a decreasing trend in the north. Rao et al. (2005) using station data for 103 stations for the period of 1971-2000 reported that, from March to May most of the stations in peninsular India show an increasing trend in the days with critical extreme maximum and minimum temperatures and $40 \%$ stations in the northern part of India show increasing trend in the days with critical extreme maximum temperature while about $80 \%$ of the stations showed increasing trend in the extremes in night temperatures. Arora et al. (2005) studied the trends in temperature over India using data for 125 stations distributed over the whole India for winter, premonsoon, monsoon and post-monsoon seasons. They reported a rising trend in most cases, except for the mean pre-monsoon temperature, the mean monsoon temperature, the pre-monsoon mean minimum temperature and the monsoon mean minimum temperature.

Sen Roy and Balling (2005), have studied the trends in maximum, minimum temperature, daily temperature range (DTR) and cloud cover over India for the summer monsoon (July and August) and winter seasons using Climate Research Unit high resolution data $\left(1^{\circ} \times 1^{\circ}\right)$ for the period of 1931 to 2002. In this study they tried to find out a relation between the cloud cover and DTR. They have reported a significant increase in the maximum and minimum temperatures for both these seasons. They have also reported that the trend in DTR is not statistically significant for India in both the seasons.

The efforts to know the temperature changes over Indian region was made by Rupa Kumar et al. (2006) by using PRECIS model for generating high resolution climate change scenario for India for the 21st century. They have reported that the extremes in maximum and minimum temperatures are expected to increase in future and they have also reported faster increase in night temperatures than the day temperatures. Sharp rise in maximum and minimum temperature over north India as compared to south India has been reported by Dash and Hunt (2007). Kothawale et al. (2010a) have reported that the maximum, minimum and mean temperatures are increasing and the increase in minimum temperature is faster than maximum temperature. Kothawale et al. (2010b) have studied the pre-monsoon daily temperature extremes over the Indian region using station data. Their study indicates increasing trend in the frequency of occurrence of hot days and hot nights and decreasing trend in cold days and cold nights over most of the parts of India. They have also reported that the frequency of occurrence of hot days has significantly increased over east coast, west coast and interior peninsula and cold days show significant decreasing trend over the western Himalayas and west coast. The three regions east coast, west coast and northwest parts of India show significant increasing trend in the frequency of hot nights. India as a whole shows increasing trend in the frequency of hot days and nights and decreasing trend in the frequency of cold days and nights.

Jain and Vijay Kumar (2012), using data for 21 river basins in India reported a rising trend in mean maximum temperature over most of the stations. Mean minimum temperature shows rising trend at some stations as well as falling trend at some stations. Annual mean temperature at most of the stations in south, central and western parts show increasing trend and some stations in the north and northeastern India showed a decreasing trend.

Studies on a regional scale are important as long term temperature changes over the Himalazyan region affect glaciers and snow cover and river discharge over northwestern Himalayas which is very important as far as water resource management in northern Indian states are concerned. The study by Bhutiyani et al. (2007) using station data for a few stations in the northwest Himalayan region shows significant increasing trend in maximum, minimum, mean and diurnal temperature range. They have also reported faster warming rate in winters and significant increasing trend 
in diurnal temperature range due to rise in both the maximum and minimum temperatures with the maximum increasing much more rapidly. A study over Himalayan-Gangetic region by Gautam et al. (2009) reported enhanced pre-monsoon warming over the area from 1979 to 2007. Subash et al. (2010) from the observational characteristics for rainfall and temperatures over central northeast India have reported significant rising trend in maximum temperature during monsoon and post-monsoon seasons and minimum temperature showing significant increasing trend during post-monsoon season and a decreasing trend in monsoon season. Nazzareno et al. (2011), using a new statistical reconstruction of annual temperature variability back to 1901 have indicated that in recent decades the warming trend over the Himalayas/Tibetan plateau has been faster than during any equivalent period in the last century. Jhajharia and Singh (2011), using data for eight stations in northeast India, observed decreasing trends in diurnal temperature ranges at three sites and increasing trend at three other sites. They also reported that temperature remained practically trendless in winter and pre-monsoon seasons and increased in the monsoon and post-monsoon seasons over northeast India. Jain et al. (2012) found a rising trend in mean maximum temperature and mean minimum temperature for most of the stations over northeast India. Falling trend in annual mean temperature is observed at some stations located in the north and northeastern India.

Most of the above studies on temperature trends in India have focused on the analysis of annual and seasonal temperature data for a single station or a group of stations. A majority of the stations in India are located in urban areas which act as heat islands. Therefore to get the correct picture of the trends in temperature over the country as whole, we have used the daily temperature dataset developed by India Meteorological Department (IMD) over the Indian landmass for the period from 1969 to 2005. Research Report 8 prepared by Srivastava et al. (June 2008) for National Climate Center, India Meteorological Department, says that the dataset is prepared by using 395 quality controlled stations distributed all over India (shown in figure 1a), with a well proven interpolation technique and the quality of the data was evaluated using cross validation technique. The meteorologically homogeneous subdivisions of India are shown in figure 1(b). In this study, an attempt has been made to find the trends in mean maximum, mean minimum, mean daily temperatures and mean daily range in temperature over different $1^{\circ} \times 1^{\circ}$ grid boxes distributed all over India.

\section{Data and methodology}

The basic datasets used in the present study are the high-resolution $\left(1^{\circ} \times 1^{\circ}\right)$ daily gridded minimum, maximum and mean temperature dataset prepared by the IMD over the Indian landmass $\left(6.5^{\circ}-38.5^{\circ} \mathrm{N}\right.$ and $66.5^{\circ}-100.5^{\circ} \mathrm{E}$ ) for the period from 1969 to 2005.

For the analysis, the seasons that are considered are: winter (January, February), pre-monsoon (March-May), monsoon (June-September) and post-monsoon (October-December).

The non-parametric Mann-Kendall test (Mann 1945; Kendall 1975) was applied to detect monotonic trends in seasonal temperatures (maximum, minimum and mean) and temperature range. Temperature range $\left(T_{\max }-T_{\min }\right)$ is calculated for each grid from daily maximum $\left(T_{\max }\right)$ and minimum $\left(T_{\min }\right)$ temperature data. From daily range, average temperature range for each month and different seasons are calculated. The significance of the trends is tested at $5 \%$ level of significance.

Mann-Kendall statistics for a series $\left(x_{1}, x_{2}, x_{3}\right.$, $\left.x_{4}, \ldots, x_{n}\right)$ is given by:

$$
\begin{gathered}
S=\sum_{i=1}^{n-1} \sum_{j=i+1}^{n} \operatorname{sgn}\left(x_{i}-x_{j}\right) \\
\operatorname{sgn}\left(x_{i}-x_{j}\right) \begin{cases}=1 & \text { if } x_{i}-x_{j}>0 \\
=0 & \text { if } x_{i}-x_{j}=0 \\
=-1 & \text { if } x_{i}-x_{j}<0\end{cases}
\end{gathered}
$$

Variance of Mann-Kendall statistics is given by:

$\operatorname{Var}(S)=\frac{n(n-1)(2 n+5)-\sum_{k=1}^{n} t_{k}\left(t_{k}-1\right)\left(2 t_{k}+1\right)}{18}$

where $n$ is the number of data points and $k$ is the number of tied groups and $t_{k}$ is the number of data points in $k$ th tied group.

The test statistics $Z$ is calculated as follows:

$$
Z= \begin{cases}=\frac{S-1}{\sqrt{\operatorname{Var}(S)}} & \text { if } S>0 \\ =0 & \text { if } S=0 \\ =\frac{S+1}{\sqrt{\operatorname{Var}(S)}} & \text { if } S<0\end{cases}
$$

\section{Result and discussion}

\subsection{Winter season (JF)}

Figure $2(\mathrm{a}-\mathrm{d})$ shows trend analysis in the winter season over India.

In the winter season, maximum temperatures show an increasing trend over the west coast 


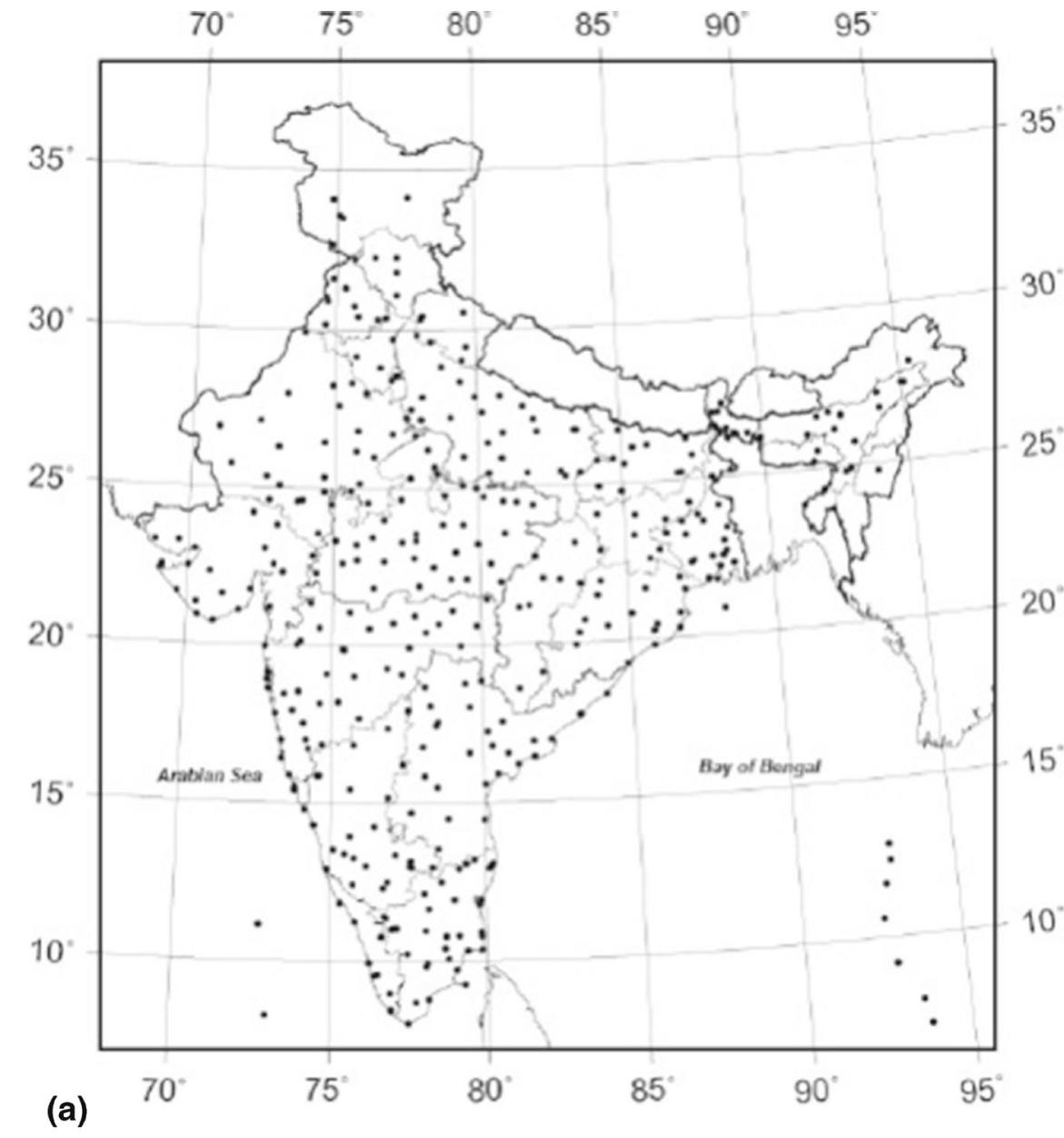

\section{Meteorological Subdivisions of India}

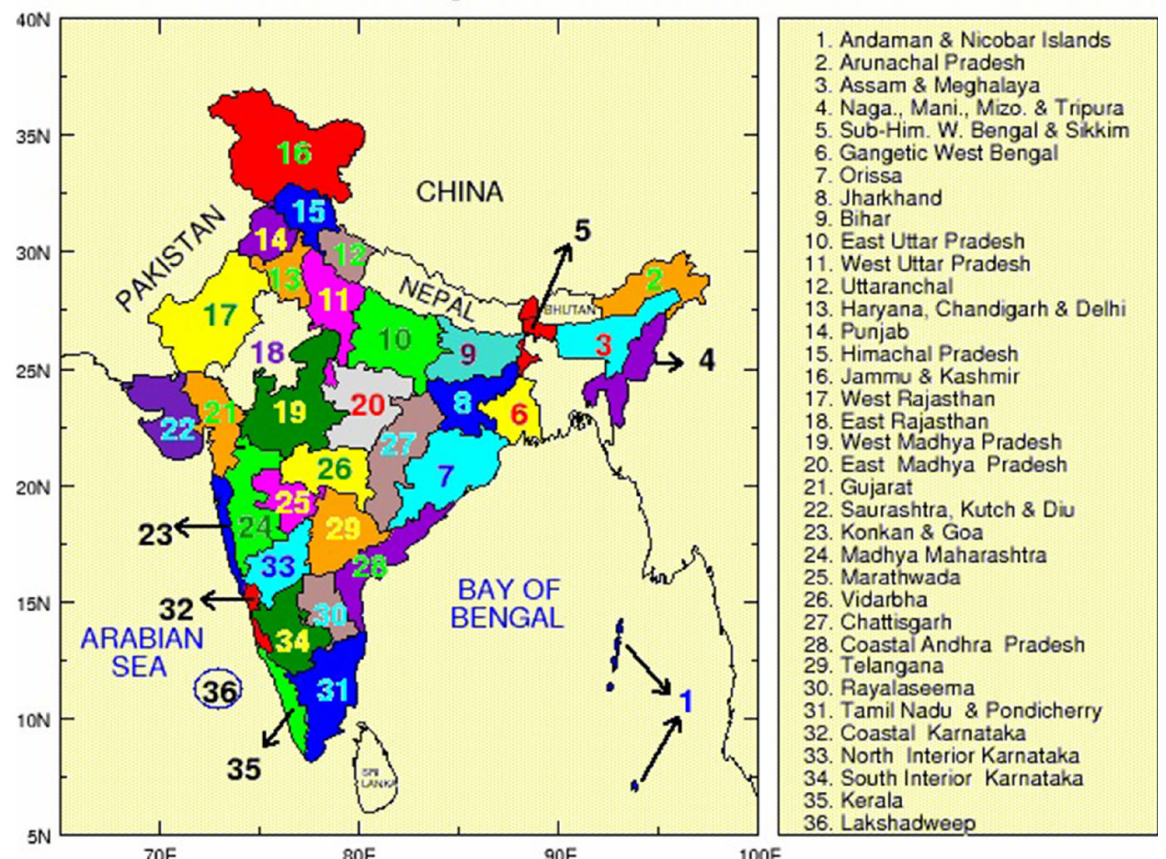

(b)

Figure 1. (a) Network of 395 stations selected for developing the gridded dataset (courtesy: National Climate Center, Research Report 8, India Meteorological Department, Pune, India). (b) Meteorologically homogeneous subdivisions over India (courtesy: Indian Institute of Tropical Meteorology, Pune, India, http://www.tropmet.res.in/IITM/india-subdiv-rev1. png). 
of India, Karnataka and Tamilnadu. West Uttar Pradesh, Uttaranchal, and a few grids over the Gangetic West Bengal show decreasing trend in maximum temperature.

Minimum temperatures show increasing trend over north India and northeast India. Saurashtra, Kutch and Diu, Kerala, and Tamilnadu also show increasing trend in minimum temperature.

Mean temperatures show increasing trend over the west coast of India and Tamilnadu.

Temperature range shows decreasing trend over north India and northeast India except over Jammu and Kashmir, some parts of Arunachal Pradesh and Assam.

\subsection{Pre-monsoon season (MAM)}

Figure $3(\mathrm{a}-\mathrm{d})$ shows trend analysis in the premonsoon season over India.

In the pre-monsoon season, maximum temperatures do not show any significant trend over the Indian region. A few grids over southern India show increasing trend whereas a few grids over Arunachal Pradesh show decreasing trend.

Minimum temperatures show significant increasing trend in Haryana, Chandigarh, and Delhi, West Uttar Pradesh, northern parts of east and west Rajasthan, subHimalayan West Bengal and Sikkim, Gangetic West Bengal, Saurashtra, Kutch and Diu, some parts of Kerala, south interior Karnataka, and Andaman and Nicobar Islands.

Mean temperatures do not show any significant trend over India.

Temperature range shows decreasing trend over north India and northeast India. These areas correspond to the areas showing significant increasing trend in minimum temperatures. Some parts of Konkan and Goa, north interior Karnataka, and Tamilnadu show increasing trend in temperature range.

\subsection{Southwest monsoon season (JJAS)}

Figure 4(a-d) shows trend analysis in the southwest monsoon season over India.

During the southwest monsoon season the southern peninsula and some part of northeast India show increasing trend in maximum temperature.

Minimum temperature shows increasing trend in the monsoon season all over India except some parts of Odisha (Orissa) and Chhattisgarh.

Mean temperatures show increasing trend all over west coast of India, West Bengal, and northeast India.

Temperature range shows decreasing trend over Himachal Pradesh, Uttaranchal, and northeast Indian states. Some parts of east Madhya Pradesh,
Chhattisgarh, Konkan and Goa, north interior Karnataka, and Kerala show increasing trend in temperature range.

\subsection{Post-monsoon season (OND)}

Figure $5(\mathrm{a}-\mathrm{d})$ shows trend analysis in the postmonsoon season over India.

In the post-monsoon season, maximum temperatures show increasing trend over most of the parts in south Indian states, Andaman and Nicobar Islands, and Lakshadweep.

Minimum temperatures show increasing trend over north Indian and northeast Indian states.

Mean temperatures show increasing trend in some parts of Kerala, Andaman and Nicobar Islands, Lakshadweep, Saurashtra, Kutch and Diu, Tamilnadu, northern parts of east and west Rajasthan, subHimalayan West Bengal and Sikkim, northeastern states of Assam, Meghalaya, Nagaland, Manipur, Mizoram, and Tripura.

Temperature range shows decreasing trend over northern parts of east and west Rajasthan, Punjab, Haryana, Chhattisgarh, Delhi and Himachal Pradesh, Uttaranchal, subHimalayan West Bengal and Sikkim, Gangetic West Bengal, and some parts of Assam and Arunachal Pradesh. Increasing trend is observed over some parts of Rajasthan, Gujarat, north interior Karnataka, Telangana, and some parts of Tamilnadu.

\section{Conclusion}

From this study it is clearly seen that, maximum temperature does not show any significant trend all over India during the pre-monsoon season. During the winter, southwest monsoon, and postmonsoon seasons the southern peninsular region shows increasing trend in maximum temperature.

Minimum temperature shows significant increasing trend over most of the states in north and northeast India during all the seasons. The west coast of India shows increasing trend in minimum temperature during the winter and southwest monsoon seasons.

Mean temperature does not show any significant trend all over India during the pre-monsoon season. But during the winter, southwest monsoon and post-monsoon seasons, west coast of India, central India, and some parts of northeast India show increasing trend.

Decreasing trend is observed in temperature range over the north and northeast Indian states during all the seasons. In the pre-monsoon, southwest monsoon and post-monsoon seasons, some parts of the west coast of India and southern 


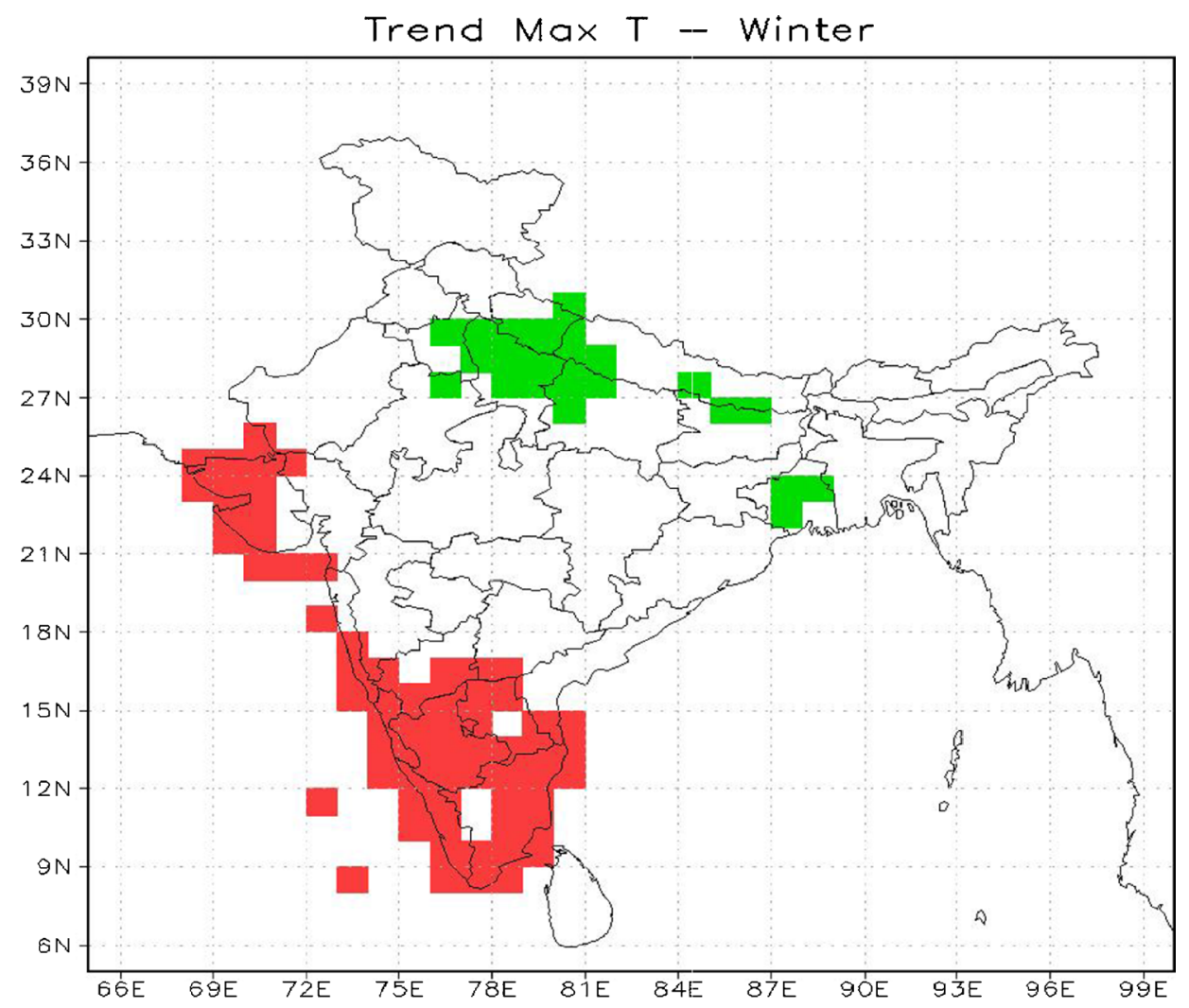

(a)

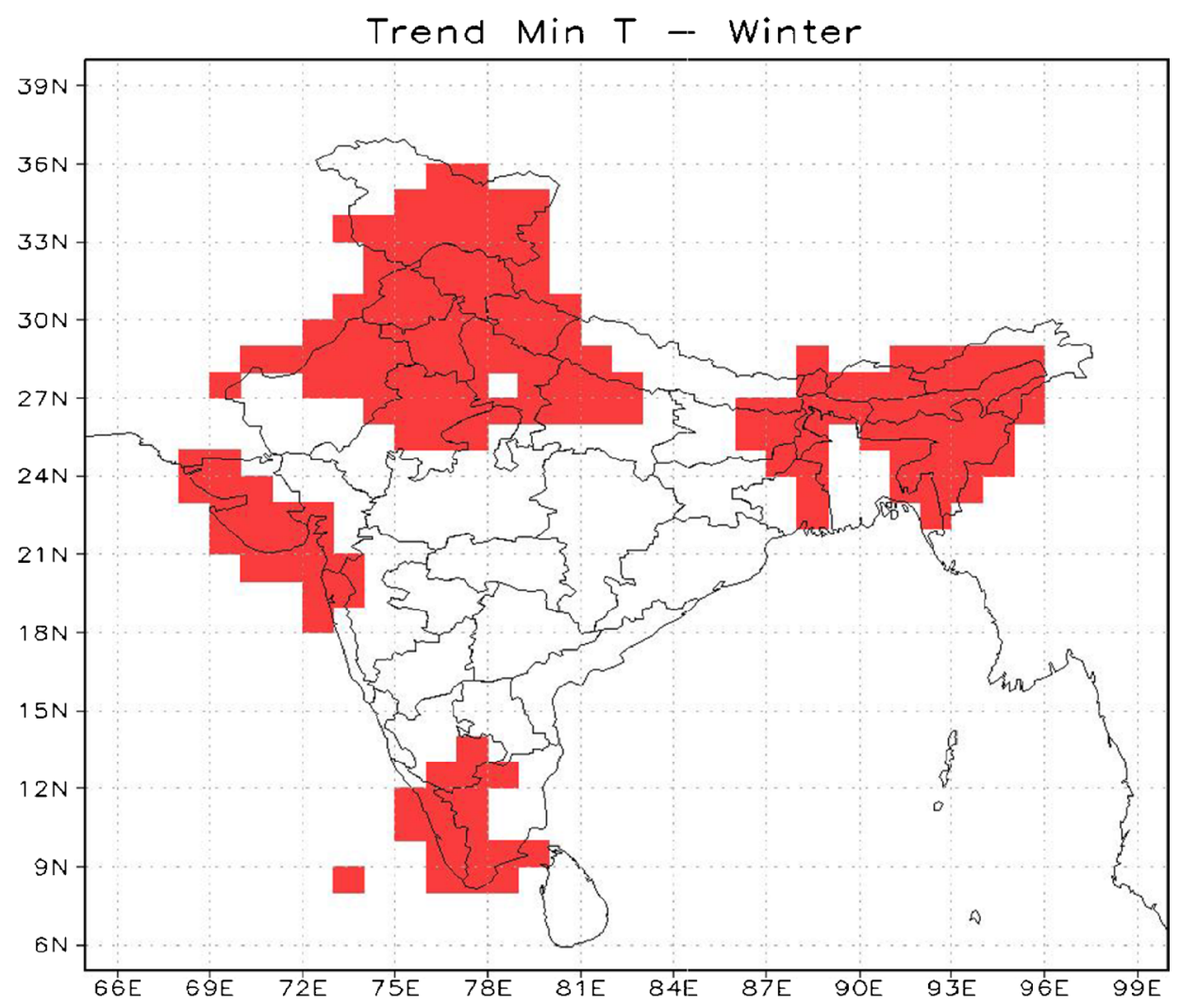

(b)

Figure 2. (a) Maximum temperature trend in winter season. (b) Minimum temperature trend in winter season. (c) Mean temperature trend in winter season. (d) Temperature range trend in winter season. Legends: $\quad$ shows decreasing trend at $5 \%$ level of significance. $\square$ shows increasing trend at $5 \%$ level of significance. 


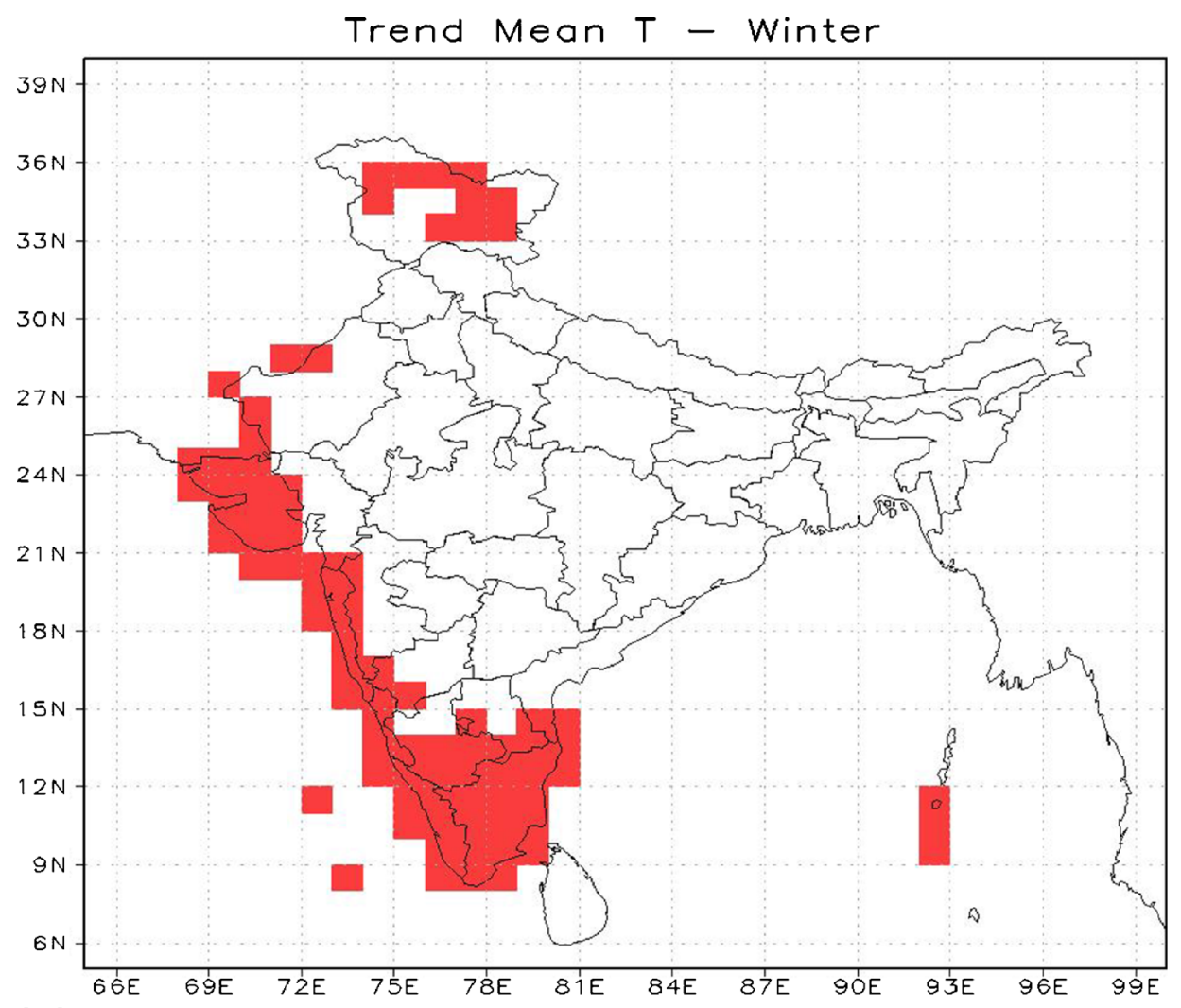

(c)

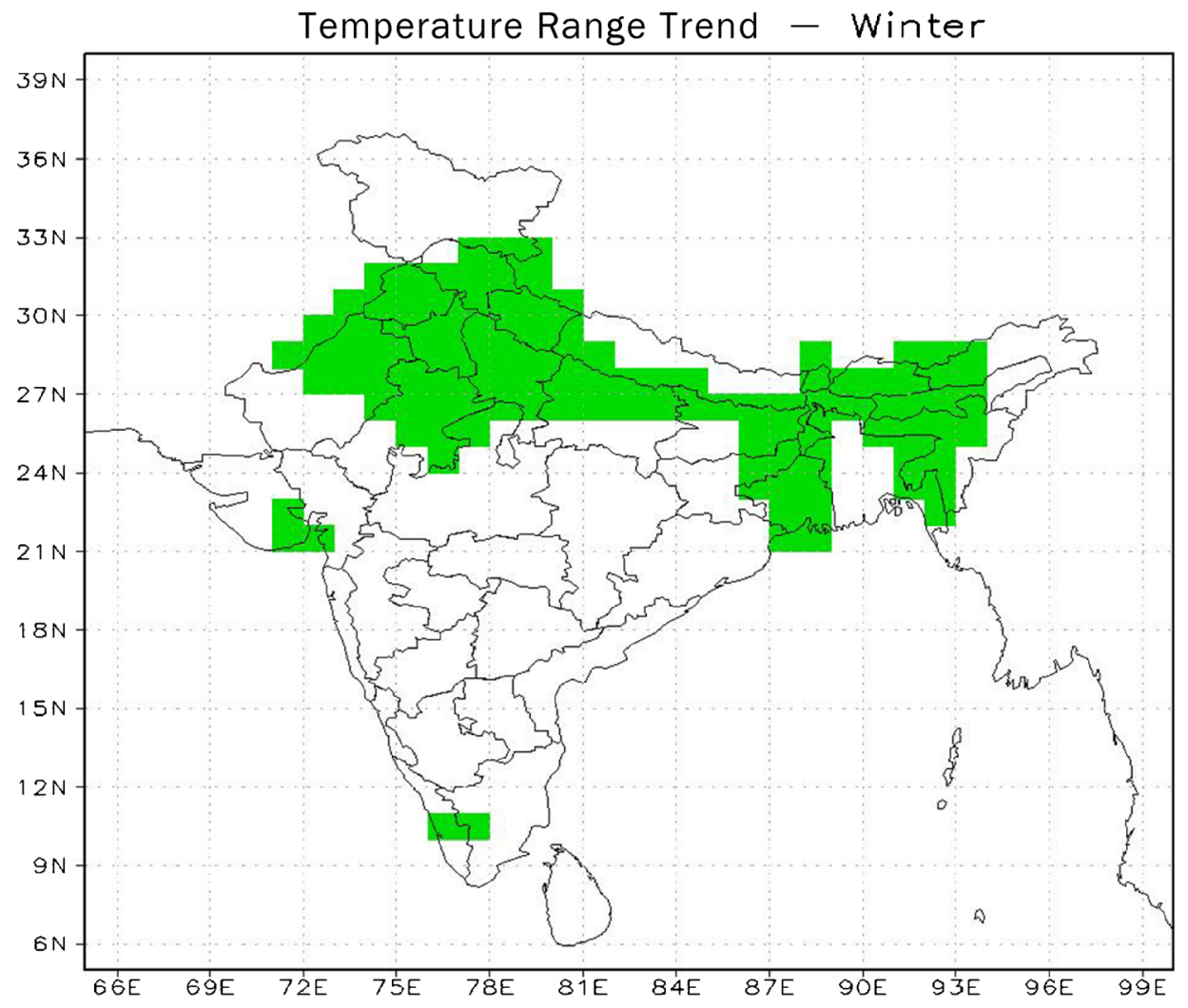

(d)

Figure 2. (Continued.) 


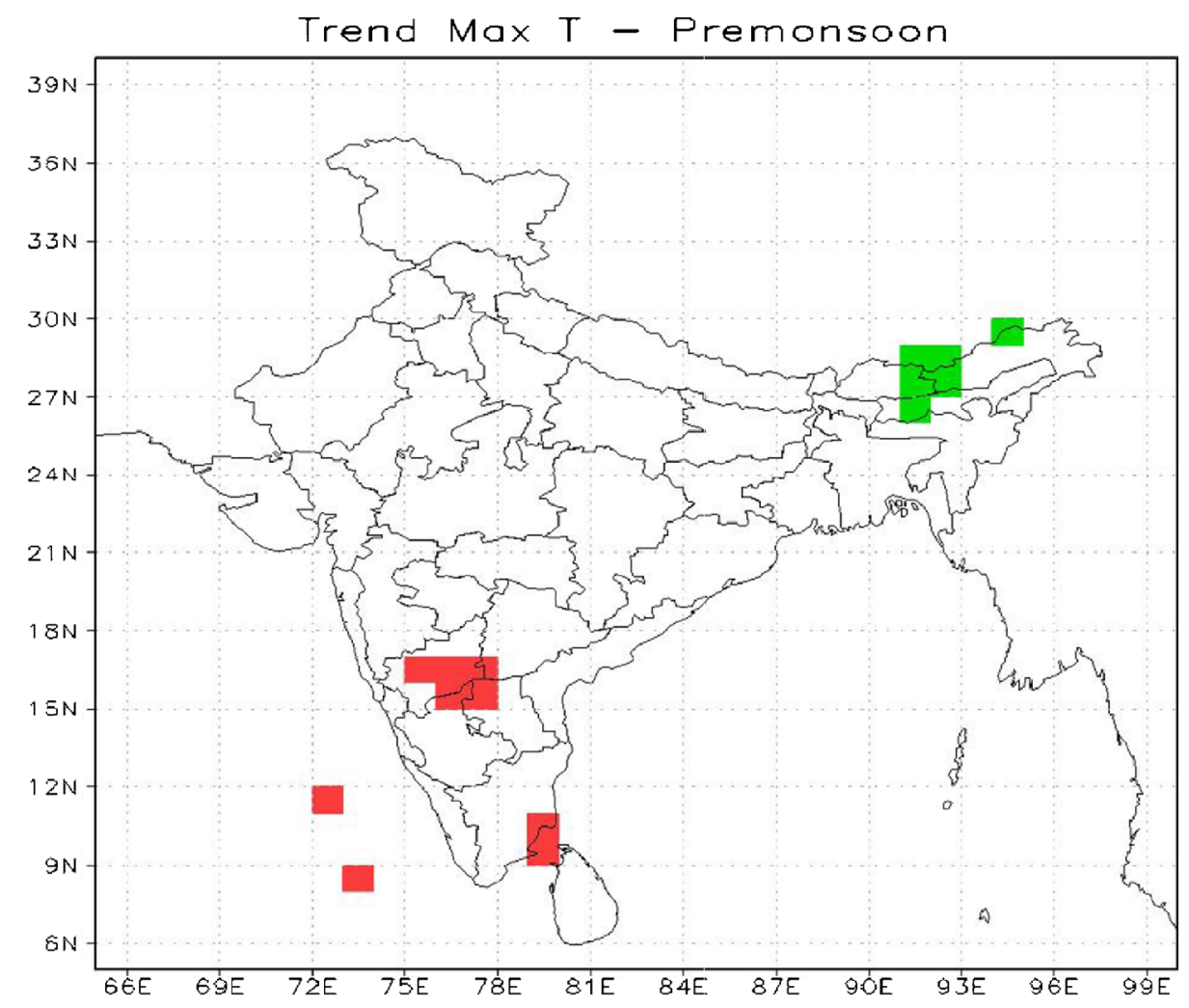

(a)

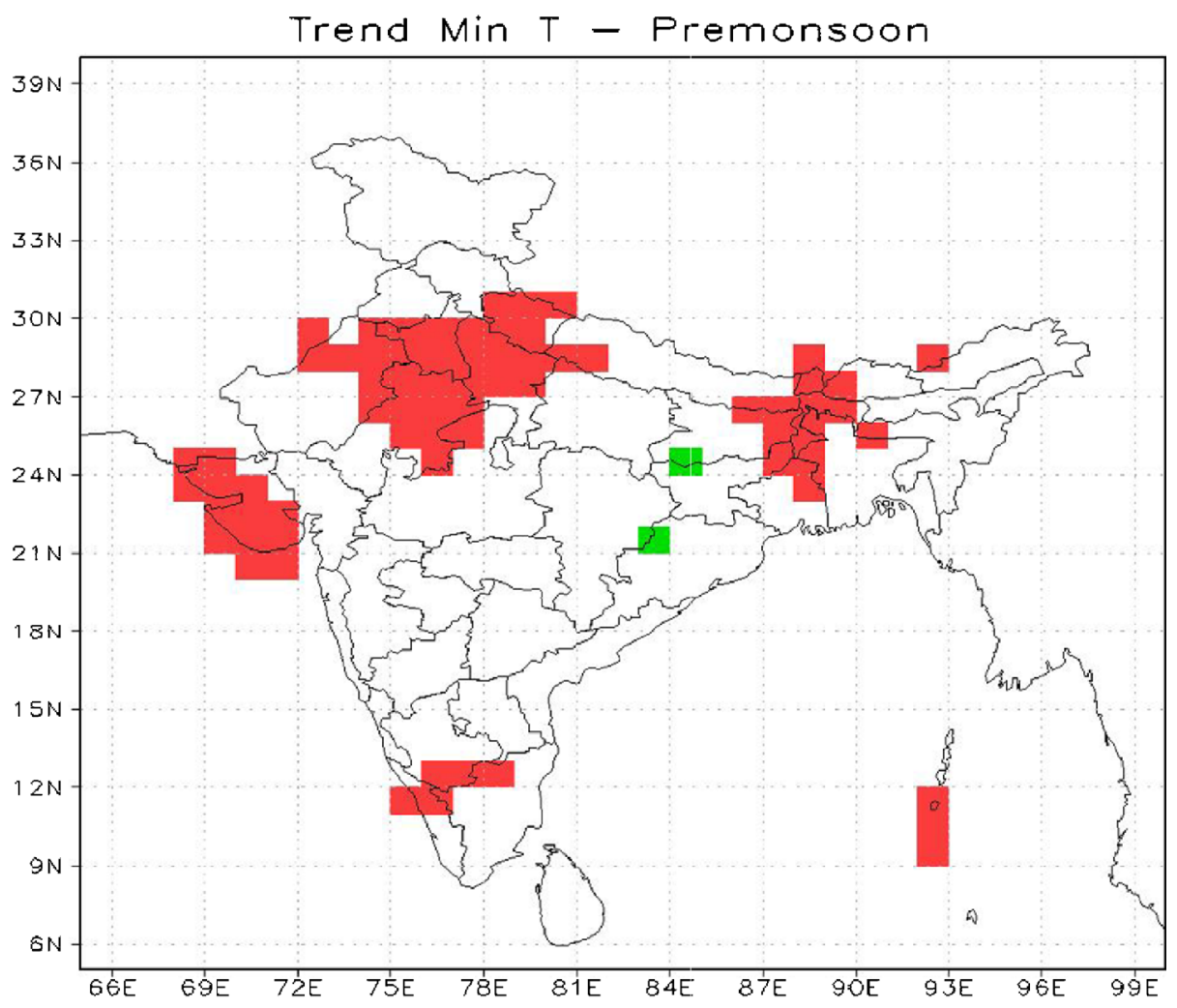

(b)

Figure 3. (a) Maximum temperature trend in pre-monsoon season. (b) Minimum temperature trend in pre-monsoon season. (c) Mean temperature trend in pre-monsoon season. (d) Temperature range trend in pre-monsoon season. Legends: shows decreasing trend at $5 \%$ level of significance. $\square$ shows increasing trend at $5 \%$ level of significance. 


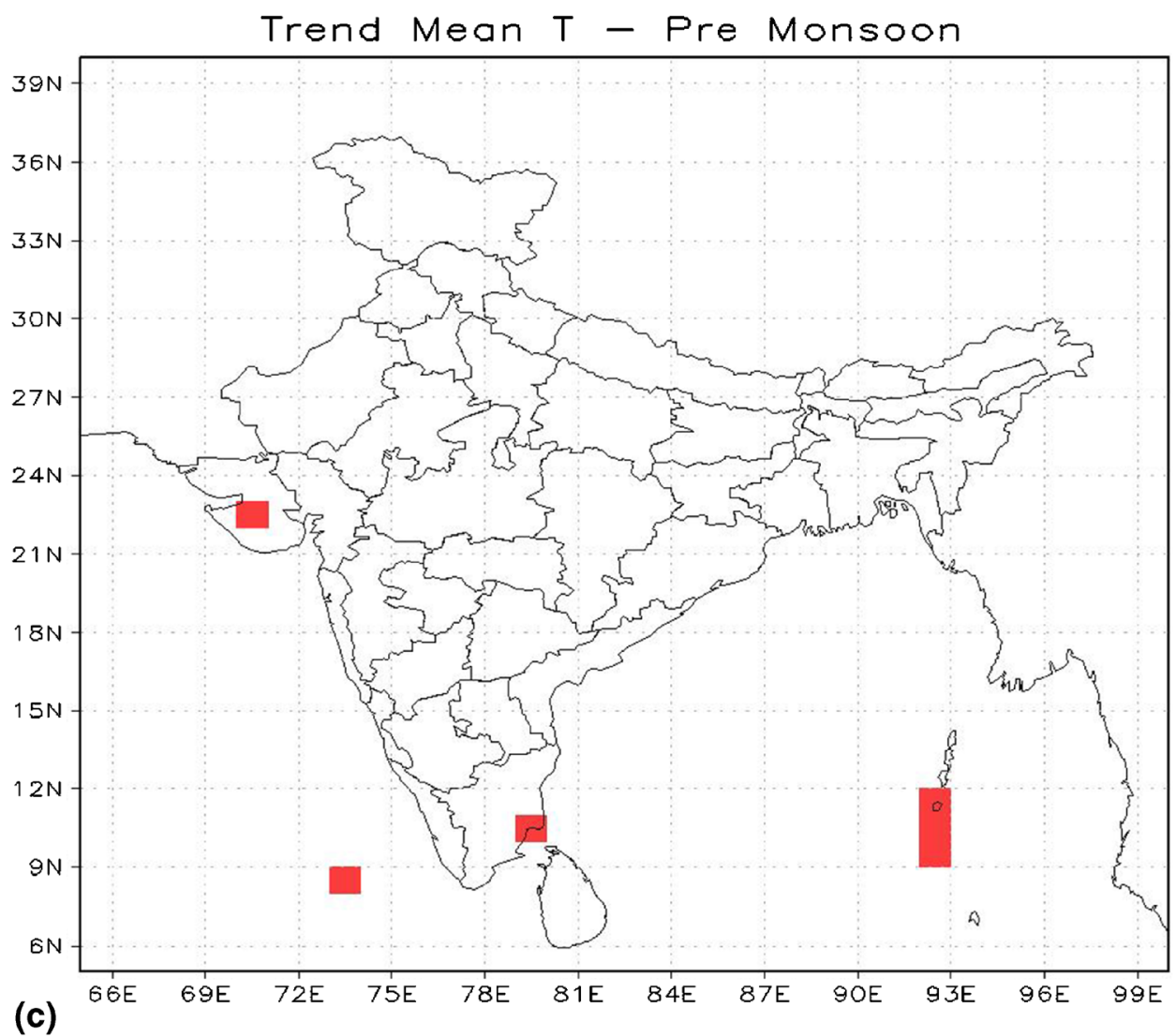

Temperature Range Trend - Pre Monsoon

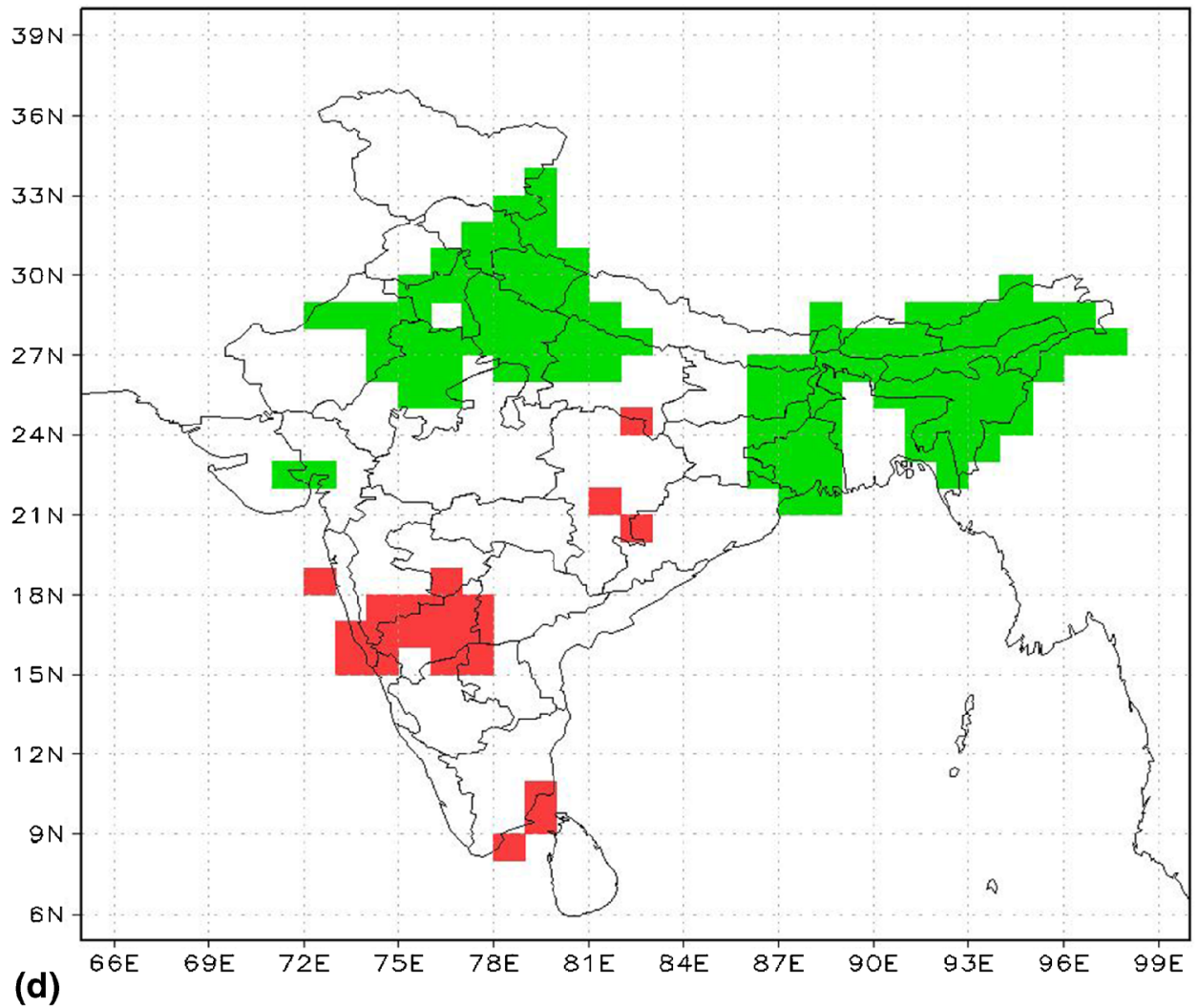

Figure 3. (Continued.) 


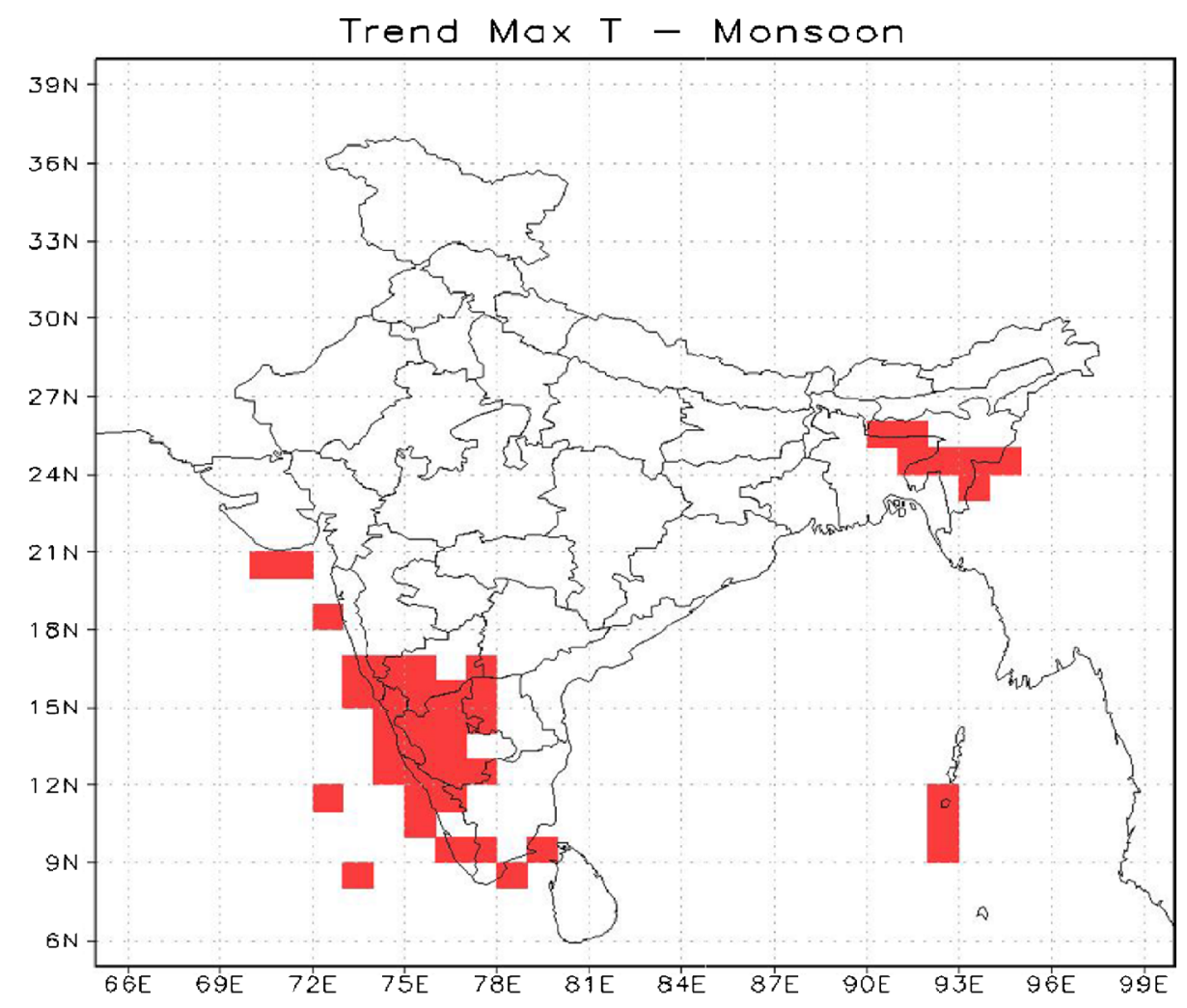

(a)

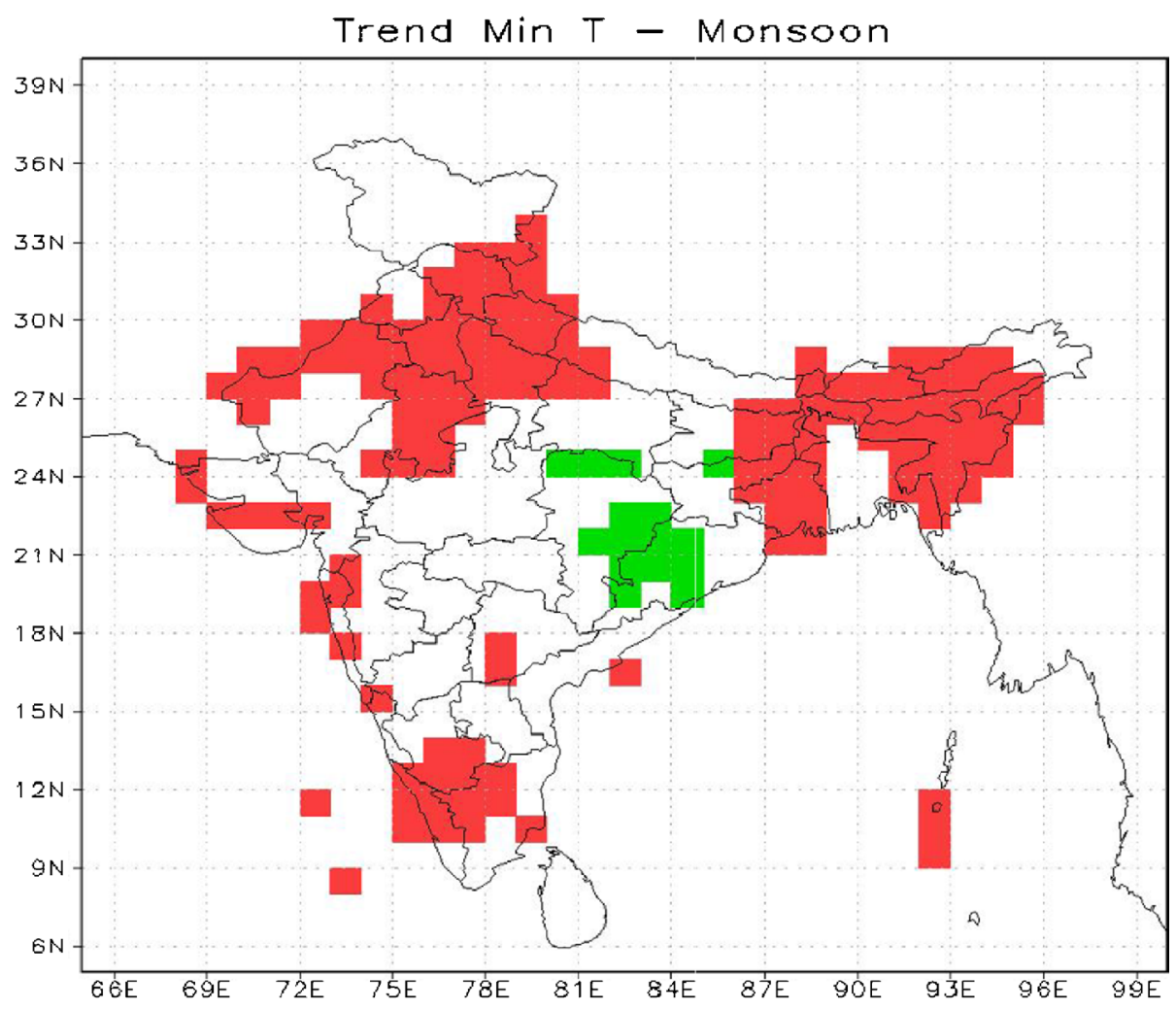

(b)

Figure 4. (a) Maximum temperature trend in the southwest monsoon season. (b) Minimum temperature trend in the southwest monsoon season. (c) Mean temperature trend in the southwest monsoon season. (d) Temperature range trend in the southwest monsoon season. Legends: - shows decreasing trend at $5 \%$ level of significance. shows increasing trend at $5 \%$ level of significance. 


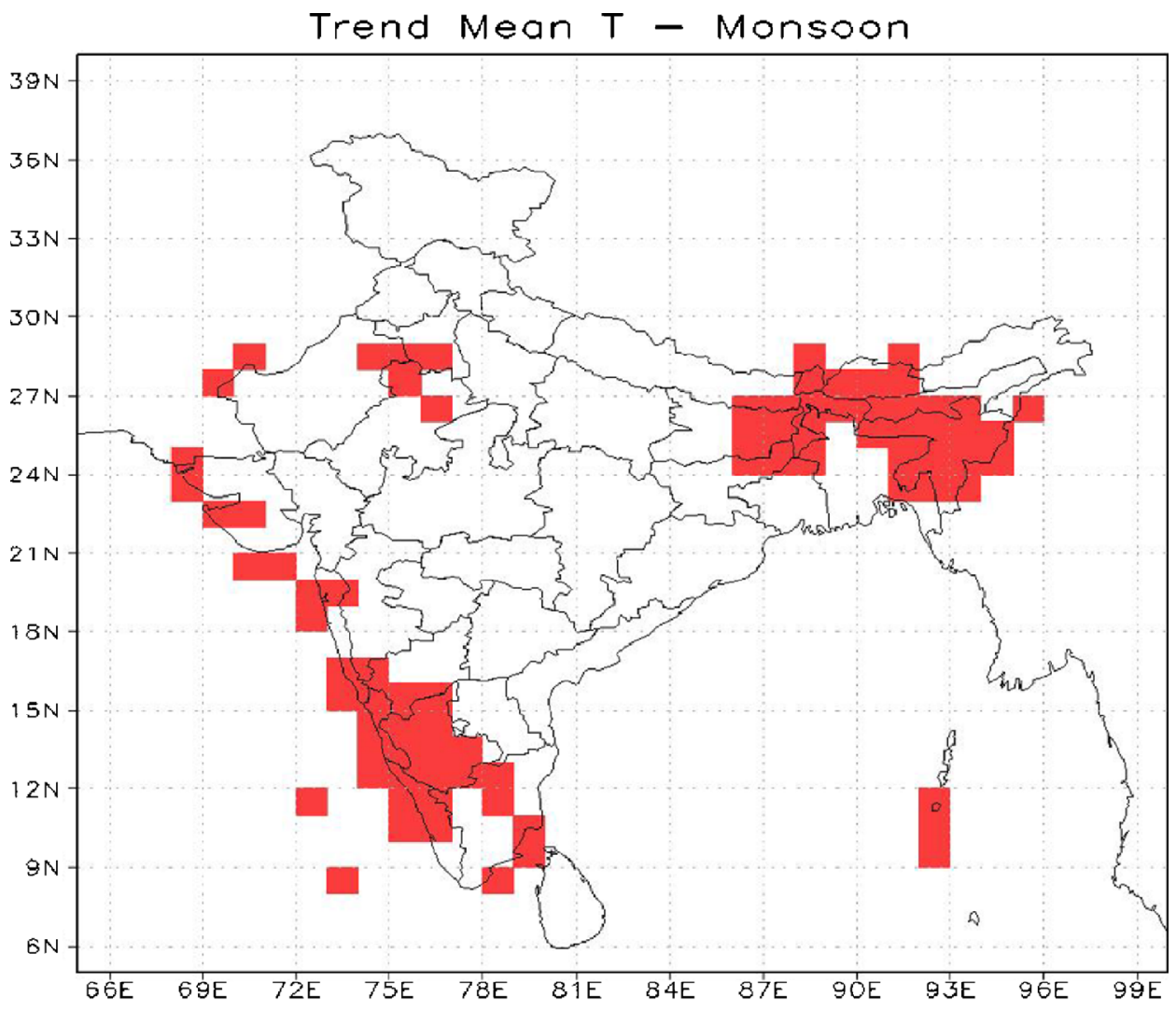

(c)

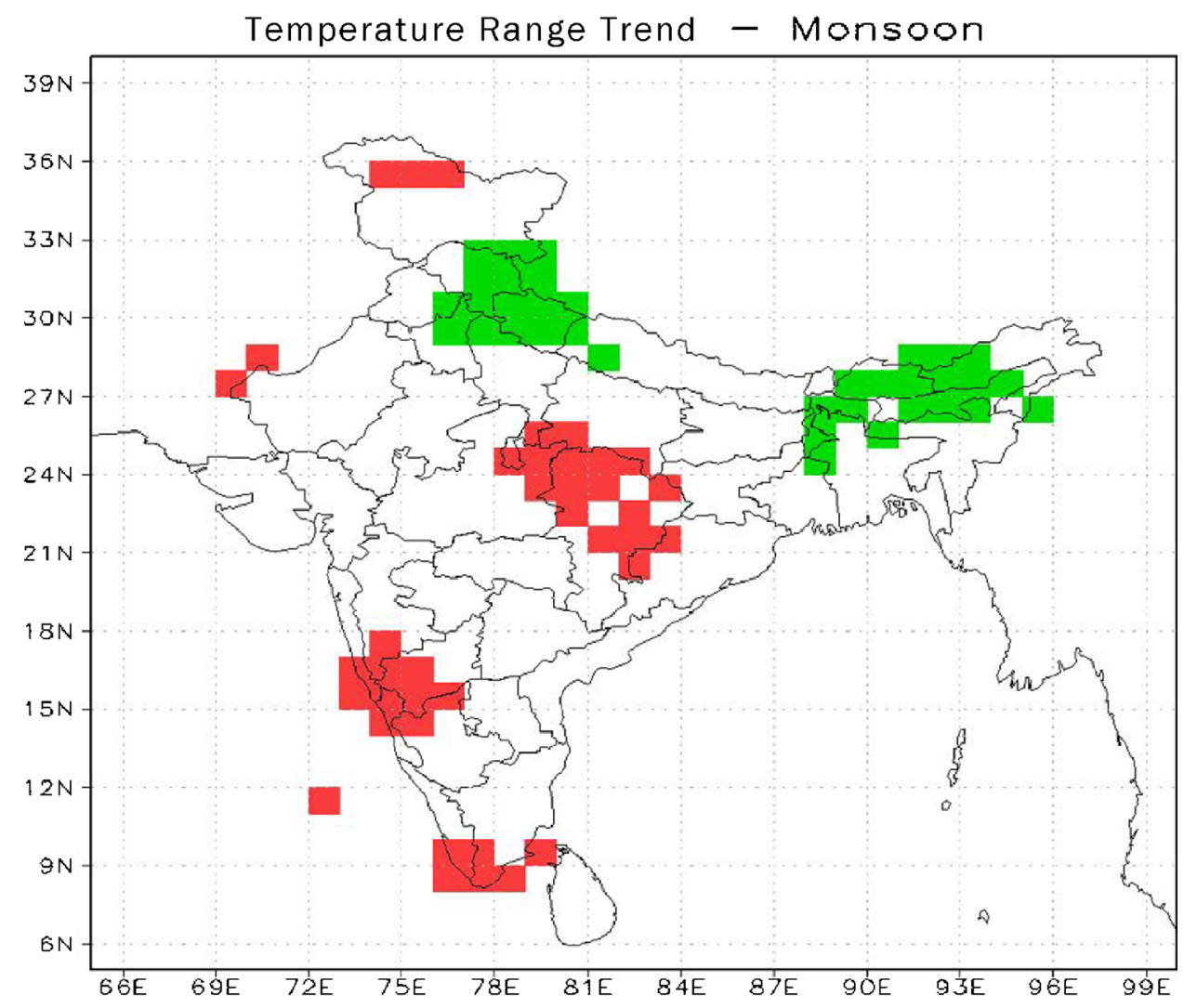

(d)

Figure 4. (Continued.) 


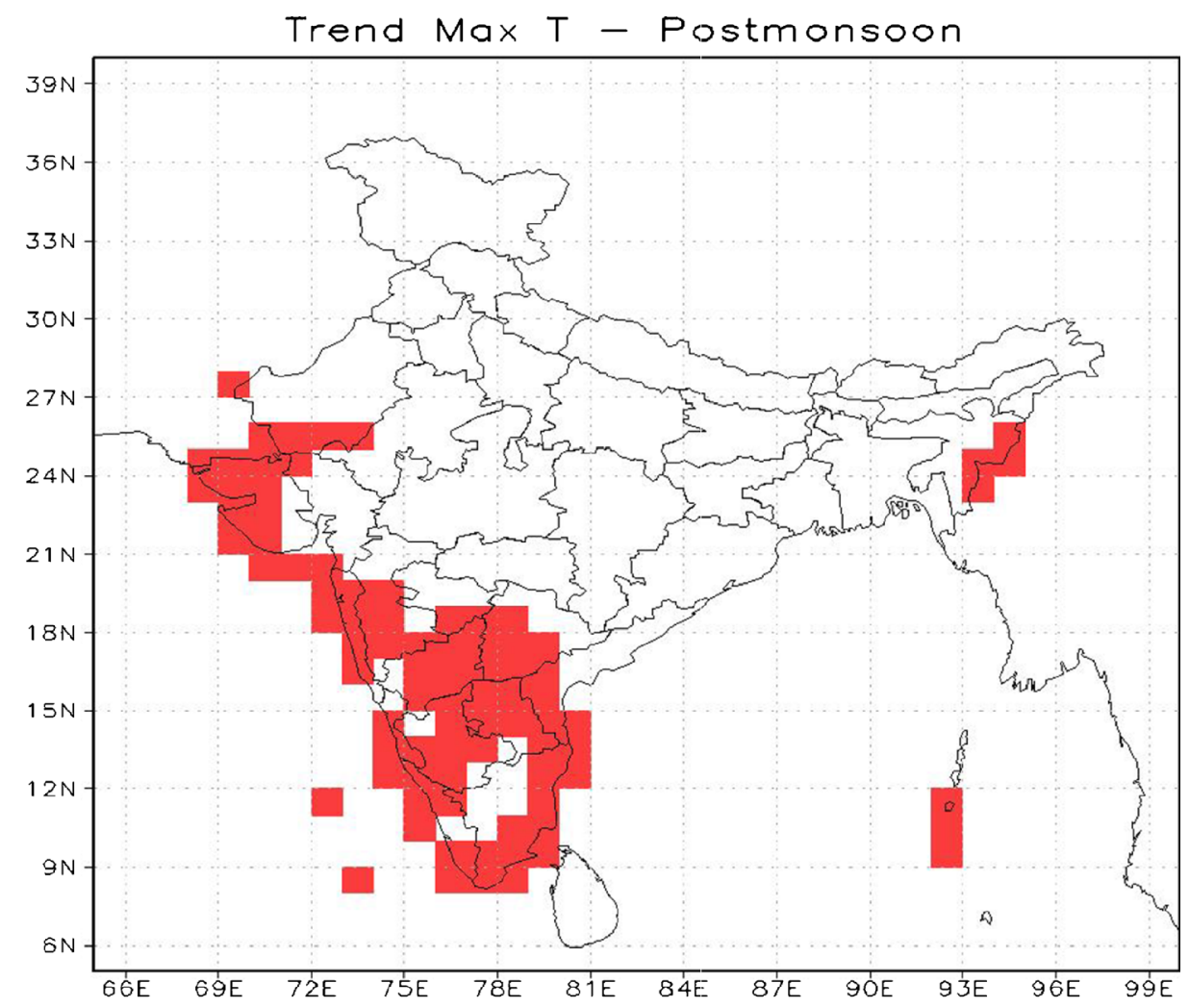

(a)

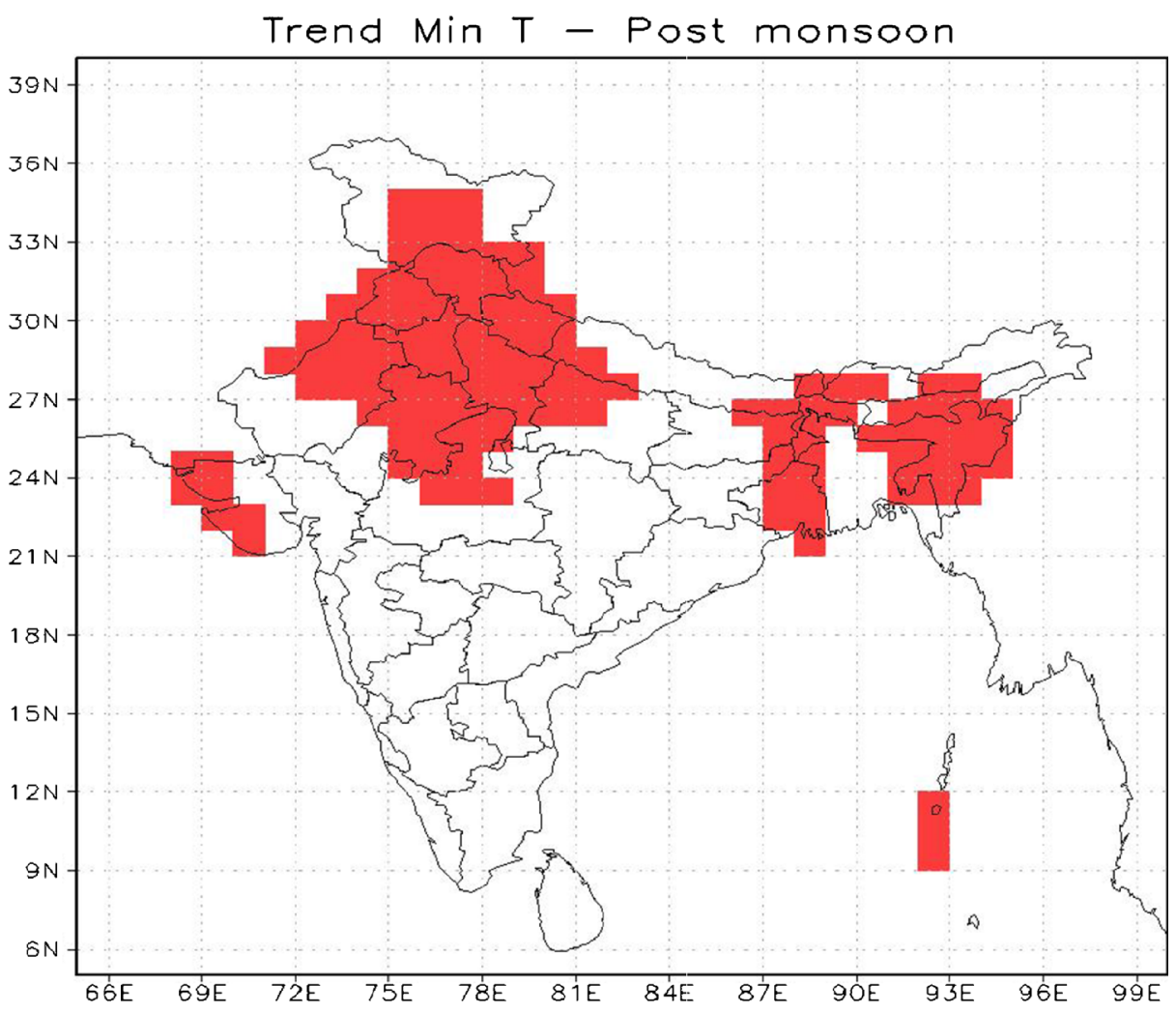

(b)

Figure 5. (a) Maximum temperature trend in post-monsoon season. (b) Minimum temperature trend in post-monsoon season. (c) Mean temperature trend in post-monsoon season. (d) Temperature range trend in post-monsoon season. Legends: shows decreasing trend at $5 \%$ level of significance. $\quad$ shows increasing trend at $5 \%$ level of significance. 


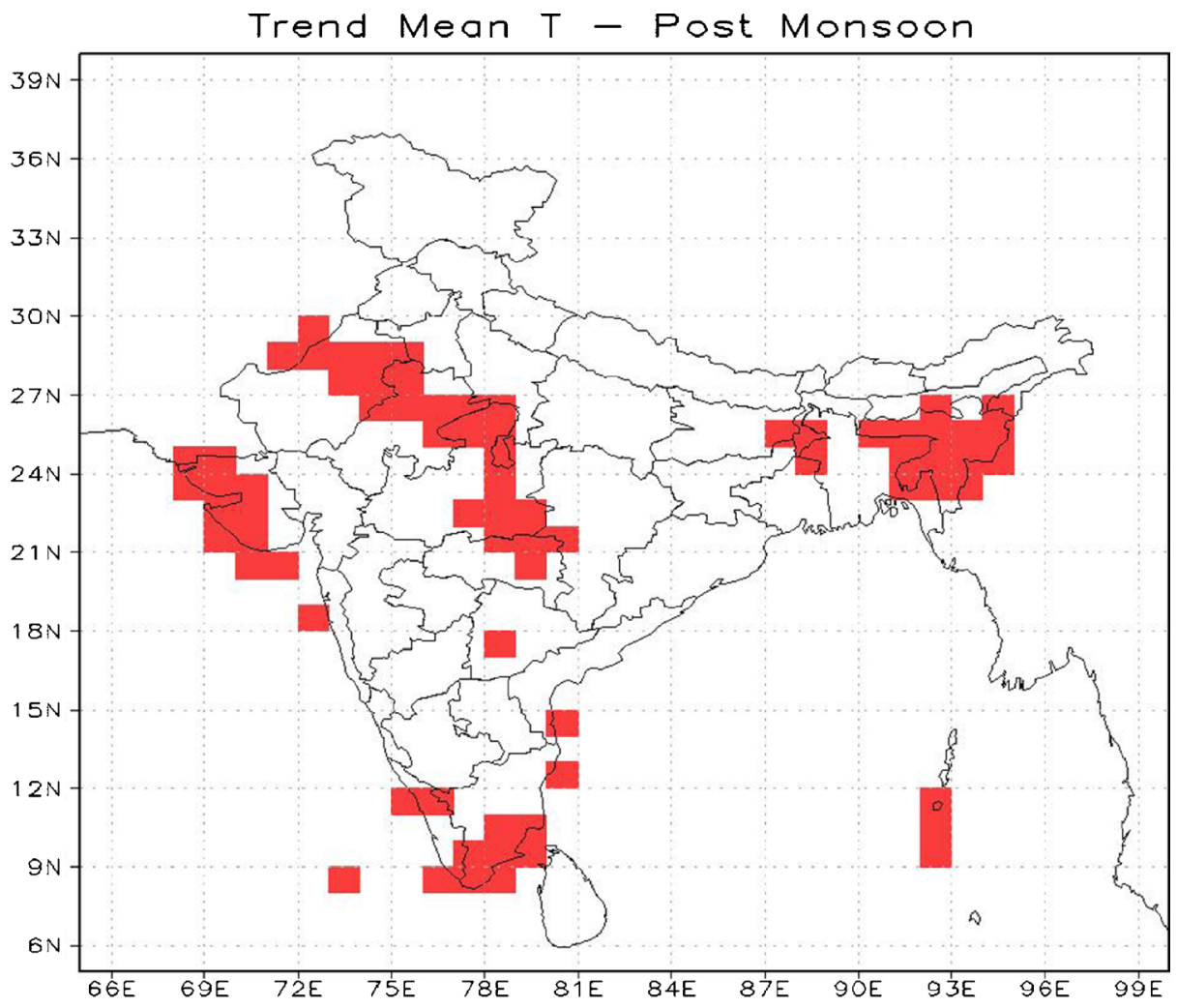

(c)

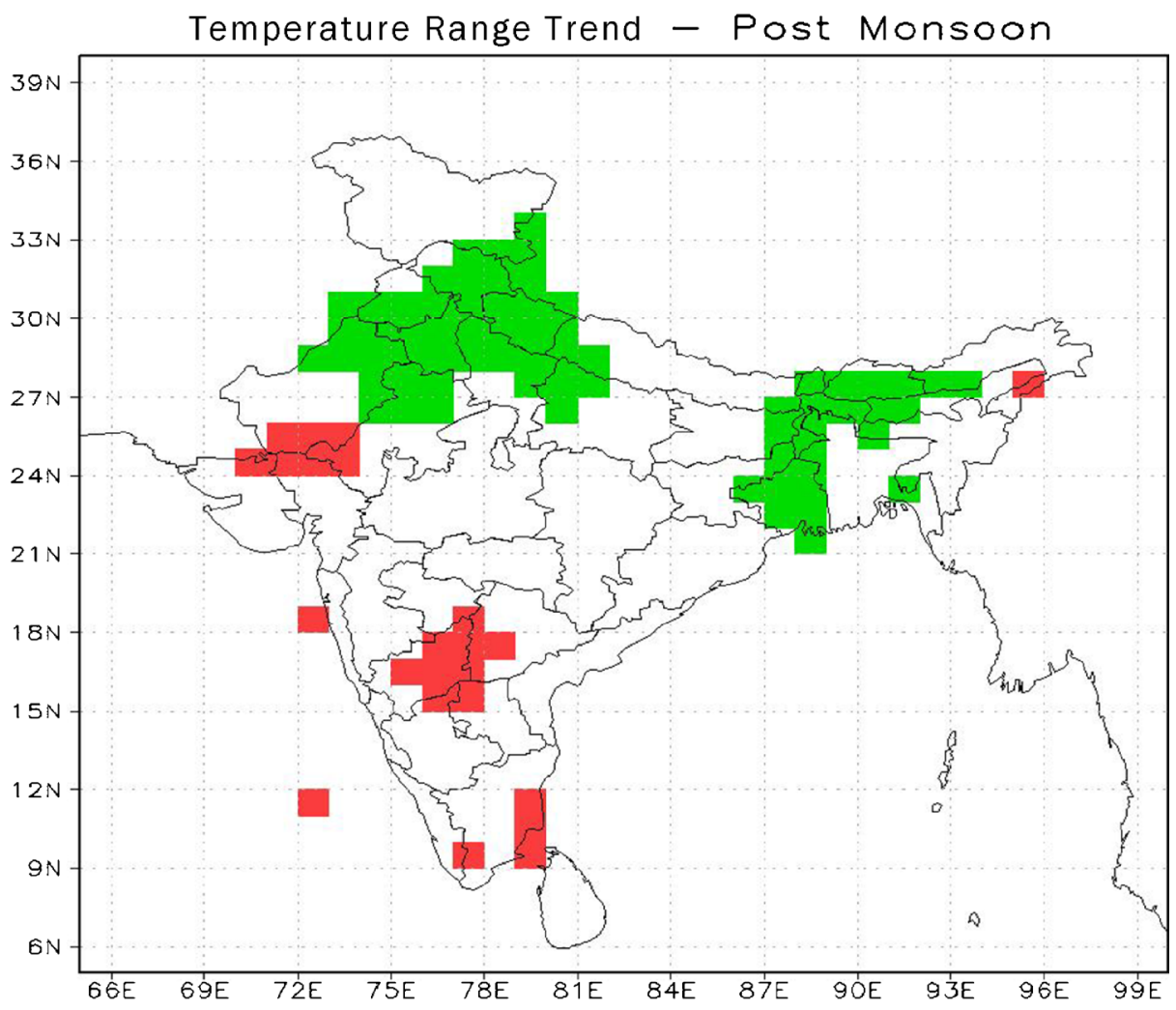

(d)

Figure 5. (Continued.) 
Indian states show an increasing trend in temperature range. Most striking feature observed over the north and northeast Indian states is that the decreasing trend in temperature range is observed at the places where there is no significant increasing trend in maximum temperature and significant increasing trend in minimum temperature.

From these observations we can conclude that the increasing trend in minimum temperature is responsible for decreasing trend in the temperature range.

In the present study, increase in the minimum temperature is prominently observed over the northern Indian states and northeast Indian states during all the seasons. The rise in the minimum temperature over this region may be due to the rapid urbanization, industrialization and increase in the number of automobiles resulting in increase in aerosol loading. Various radiative feedback mechanisms could be therefore responsible for the increasing trend in the minimum temperature. With the increase in temperature the atmosphere can hold more water vapour, which could result in increased clouding. Depending on the type of cloud cover an increase in minimum temperature and decrease in maximum temperature is possible. It is observed that there are grids where there is no increasing trend in maximum temperature. Decrease in the temperature range is observed mainly due to the increasing trend in minimum temperature.

In brief, over the west coast of India and southern Indian states, mean maximum and mean temperature show increasing trend during the winter, southwest monsoon and post-monsoon seasons. Minimum temperature shows an increasing trend over more grids in north Indian states as compared to south Indian states.

\section{Acknowledgements}

The authors are thankful to University Grants Commission, India for funding this research work and Department of Atmospheric and Space Sciences, University of Pune and Sir Parashurambhau College, Pune for providing the facilities for the work. The authors are also thankful to India Meteorological Department for making the data available for this research work. They thank Dr Anandakumar Karipot and Dr Makarand Kulkarni for their continuous encouragement and help for the research work. They also thank the anonymous reviewer for valuable comments which have led to vast improvement of the paper.

\section{References}

Arora Manohar, Goel N K and Singh Pratap 2005 Evaluation of temperature trends over India/Evaluation de tendances de température en Inde; Hydrol. Sci. J. 50(1) 93.

Bhutiyani M R, Kale V S and Pawar N J 2007 Longterm trends in maximum, minimum and mean annual air temperatures across the northwestern Himalaya during the twentieth century; Climatic Change 85 159-177. doi: 10.1007/s10584-006-9196-1.

Dash S K and Hunt J C R 2007 Variability of climate change in India; Curr. Sci. 93(6) 782-788.

Gautam R, Hsu N C, Lau K M, Tsay S C and Kafatos M 2009 Enhanced pre-monsoon warming over the Himalayan-Gangetic region from 1979 to 2007; Geophys. Res. Lett. 36 L07704.

Hingane L S, Rupa Kumar K and Ramana Murthy Bh V 1985 Long-term trends of surface air temperature in India; J. Climatol. 5(5) 521-528.

Jain S K and Kumar Vijay 2012 Trend analysis of rainfall and temperature data for India; Curr. Sci. 102(1) 37-49.

Jain S K, Vijay Kumar and Saharia M 2012 Analysis of rainfall and temperature trends in north east India; Int. J. Climatol. (wileyonlinelibrary.com), doi: 10.1002/joc.3483.

Jhajharia Deepak and Singh Vijay P 2011 Trends in temperature, diurnal temperature range and sunshine duration in north east India; Int. J. Climatol. 31 1353-1367. doi: $10.1002 /$ joc. 2164 .

Kendall M G 1975 Rank Correlation Methods; Griffin, London.

Kothawale D R, Munot A A and Krishna Kumar K 2010a Surface air temperature variability over India during 1901-2007, and its association with ENSO; Clim. Res. 42(2) 89-104.

Kothawale D R, Revadekar J V and Rupa Kumar K 2010b Recent trends in pre-monsoon daily temperature extremes over India; J. Earth Syst. Sci. 119(1) 51-65.

Mann H B 1945 Nonparametric tests against trend; Econometrica 13 245-259.

Nazzareno Diodato, Gianni Bellocchi and Gianni Tartari 2011 How do Himalayan areas respond to global warming?; Int. J. Climatol., doi: 10.1002/joc.2340.

Pant G B and Rupa Kumar K 1997 Climates of south Asia (Chichester: John Wiley \& Sons), 320p. (ISBN 0-47194948-5).

Pramanik S K and Jagannathan P 1954 Climatic changes in India rainfall; Indian J. Meteorol. Geophys. 4 291-309.

Rao G S P, Murthy M K and Joshi U R 2005 Climate change over India as revealed by critical extreme temperature analysis; Mausam 56 601-608.

Rupa Kumar K, Krishna Kumar K and Pant G B 1994 Diurnal asymmetry of surface temperature trends over India; Geophys. Res. Lett. 21(8) 677-680.

Rupa Kumar K, Sahai A K and Krishna Kumar K 2006 High-resolution climate change scenarios for India for the 21st century; Curr. Sci. 90(3) 334-345.

Sen Roy S and Balling R C 2005 Analysis of trends in maximum and minimum temperature, diurnal temperature range, and cloud cover over India; Geophys. Res. Lett. 32(12) L12702. doi: 10.1029/2004GL022201.

Sinha Ray K C and De U S 2003 Climate change in India as evidenced from instrumental records; WMO Bull. 52(1) $53-59$.

Srivastava H N, Dewan B N, Dikshit S K, Rao P G S, Singh S S and Rao K R 1992 Decadal trends in climate over India; Mausam 43 7-20. 
Srivastava A K, Rajeevan M and Kshirsagar S R 2008 Development of a high resolution daily gridded temperature data set (1969-2005) for the Indian region; National Climate Center Research Report 8, India Meteorological Department, Pune, India.
Subash N, Sikka A K and Ram Mohan H S 2010 An investigation into observational characteristics of rainfall and temperature in central northeast India - a historical perspective 1889-2008; Theor. Appl. Climatol., doi: 10.1007/s00704-010-0299-2.

MS received 2 August 2013; revised 19 December 2013; accepted 31 December 2013 